\title{
The Synthesis and Vibrational Spectra of Some Dihalides of Divalent Tellurium
}

\author{
P. KLABOE, ${ }^{a}$ C. J. NIELSEN, ${ }^{a}$ R. SUCHI ${ }^{a}$ and O. VIKANE ${ }^{b}$
}

${ }^{a}$ Department of Chemistry, University of Oslo, Oslo 3, Norway and ${ }^{b}$ Department of Chemistry, University of Tromsø, N-9001 Tromsø, Norway

Salts containing [ArTeXY] $]^{-} \mathrm{X}=\mathrm{I}, \mathrm{Br} ; \mathrm{Y}=\mathrm{I}, \mathrm{Br}, \mathrm{Cl}$ were synthesized and preliminary $\mathrm{X}$-ray crystallographic data are reported. The infrared and Raman spectra of six salts containing the $[\mathrm{ArTeXY}]^{-}$ion were recorded below $400 \mathrm{~cm}^{-1}$, and compared with spectra of the cations. From these data the three fundamentals connected with the approximately linear $\mathrm{X}-\mathrm{Te}-\mathrm{Y}$ linkage (two stretches and a bending mode) were tentatively assigned. Simple force fields were derived for the anions which reproduced the wave numbers of the observed fundamentals satisfactorily.

Aryltellurenylhalides and pseudohalides, ArTeX ( $\mathrm{X}=$ uninegative ion), are known to be relatively unstable. The first members of this class to be prepared were $p$-methoxyphenyltellurenyl methanethiosulfonate and p-methoxyphenyltellurenyl benzenethiosulfonate. $^{1}$ For several years the only known tellurenyl halide was 2-naphthyltellurenyl iodide. $^{2}$ Recently several aryltellurenyl bromides and iodides, comprising $\mathrm{C}_{6} \mathrm{H}_{5} \mathrm{TeBr}, \mathrm{C}_{6} \mathrm{H}_{5} \mathrm{TeI}$, 4$\left(\mathrm{CH}_{3} \mathrm{O}\right) \mathrm{C}_{6} \mathrm{H}_{4} \mathrm{TeI}, 4-\left(\mathrm{C}_{6} \mathrm{H}_{5}\right) \mathrm{C}_{6} \mathrm{H}_{4} \mathrm{TeBr}, 4-\left(\mathrm{C}_{6} \mathrm{H}_{5}\right)$ $\mathrm{C}_{6} \mathrm{H}_{4}$ TeI, and 3,4-( $\left(\mathrm{CH}_{3}\right)_{2} \mathrm{C}_{6} \mathrm{H}_{3} \mathrm{TeI}$, were reported. ${ }^{3}$

We have recently published the synthesis ${ }^{4}$ and infrared and Raman spectra ${ }^{5}$ of tetramethylammonium phenyldithio- and phenyldiselenocyanatotellurate(II), and in a recent paper Petragnani et al. report the synthesis and Raman spectra of several tetraorganylphosphonium dihaloaryltellurates(II). However, attempts to prepare methyltriphenylphosphonium diiodophenyl- and bromoiodophenyltellurate(II) were reported to be unsuccessful. ${ }^{6}$

In the present paper we investigate the syntheses, crystal data and the infrared and Raman spectra of six salts containing the dihaloaryltellurate(II) ion.
The anions in the present compounds are: diiodophenyltellurate(II), $\mathrm{C}_{6} \mathrm{H}_{5} \mathrm{TeI}_{2}{ }^{-}$, bromoiodophenyltellurate(II), $\mathrm{C}_{6} \mathrm{H}_{5} \mathrm{TeBrI}^{-}$, dibromophenyltellurate(II), $\mathrm{C}_{6} \mathrm{H}_{5} \mathrm{TeBr}_{2}^{-}$, bromochlorophenyltellurate(II), $\mathrm{C}_{6} \mathrm{H}_{5} \mathrm{TeBrCl}^{-}$, together with 4- $\left(\mathrm{C}_{2} \mathrm{H}_{5} \mathrm{O}\right) \mathrm{C}_{6} \mathrm{H}_{4} \mathrm{TeI}_{2}^{-}$, and $4-\left(\mathrm{C}_{2} \mathrm{H}_{5} \mathrm{O}\right) \mathrm{C}_{6} \mathrm{H}_{4} \mathrm{TeBrI}^{-}$.

From the known stability of phenyltellurenylbromide and iodide, at least in aprotic solvents, ${ }^{3}$ the most plausible reaction path to the isolated products is:

$\mathrm{C}_{6} \mathrm{H}_{5} \mathrm{TeTeC}_{6} \mathrm{H}_{5}+\mathrm{X}_{2}=2 \mathrm{C}_{6} \mathrm{H}_{5} \mathrm{TeX}$

$\mathrm{C}_{6} \mathrm{H}_{5} \mathrm{TeX}+\left(\mathrm{C}_{6} \mathrm{H}_{5}\right)_{4} \mathrm{AsY}=$

$\left[\left(\mathrm{C}_{6} \mathrm{H}_{5}\right)_{4} \mathrm{As}\right]\left[\mathrm{C}_{6} \mathrm{H}_{5} \mathrm{TeXY}\right]$

Here $X_{2}$ is bromine or iodine, and $Y$ is chloride, bromide, or iodide. Due to the large cation used, the compounds crystallized readily from acetonitrile. Attempts to prepare the compounds in protic solvents like methanol were not successfull.

\section{EXPERIMENTAL}

Diphenylditelluride was prepared as described by Haller and Irgolic. ${ }^{7}$ Space groups and unit cell dimensions were determined from single-crystal oscillation and Weissenberg photographs, using $\mathrm{Cu} K \alpha$ radiation. The unit cell dimensions are believed to be accurate to within $0.5 \%$. Densities were determined by flotation. Melting points are uncorrected.

Tetraphenylarsonium diiodophenyltellurate(II), $\left[\left(\mathrm{C}_{6} \mathrm{H}_{5}\right)_{4} \mathrm{As}\right]\left[\mathrm{C}_{6} \mathrm{H}_{5} \mathrm{TeI}_{2}\right]$ (Number I, Table 1). To a solution of $1.25 \mathrm{mmol}(0.5 \mathrm{~g})$ of diphenylditelluride in $30 \mathrm{ml}$ warm acetonitrile was added, under 
Table 1. Numbering and formula of the tellurium(II) compounds studied as well as certain reference substances.

\begin{tabular}{ll}
\hline Number & \\
\hline I & {$\left[\left(\mathrm{C}_{6} \mathrm{H}_{5}\right)_{4} \mathrm{As}\right]\left(\mathrm{C}_{6} \mathrm{H}_{5} \mathrm{TeII}\right)$} \\
II & {$\left[\left(\mathrm{C}_{6} \mathrm{H}_{5}\right)_{4} \mathrm{As}\right]\left(\mathrm{C}_{6} \mathrm{H}_{5} \mathrm{TeIBr}\right)$} \\
III & {$\left[\left(\mathrm{C}_{6} \mathrm{H}_{5}\right)_{4} \mathrm{As}\right]\left(\mathrm{C}_{6} \mathrm{H}_{5} \mathrm{TeBrBr}\right)$} \\
IV & {$\left[\left(\mathrm{C}_{6} \mathrm{H}_{5}\right)_{4} \mathrm{As}\right]\left(\mathrm{C}_{6} \mathrm{H}_{5} \mathrm{TeBrCl}\right)$} \\
V & {$\left[\left(\mathrm{C}_{6} \mathrm{H}_{5}\right)_{3} \mathrm{PC} \mathrm{CH}_{3}\right]\left(\mathrm{C}_{2} \mathrm{H}_{5} \mathrm{OC}_{6} \mathrm{H}_{4} \mathrm{TeII}\right)$} \\
VI & {$\left[\left(\mathrm{C}_{6} \mathrm{H}_{5}\right)_{3} \mathrm{PCH} \mathrm{H}_{3}\right]\left(\mathrm{C}_{2} \mathrm{H}_{5} \mathrm{OC}_{6} \mathrm{H}_{4} \mathrm{TeIBr}\right)$} \\
VII & {$\left[\left(\mathrm{C}_{6} \mathrm{H}_{5}\right)_{4} \mathrm{As}\right] \mathrm{Cl}$} \\
VIII & {$\left[\left(\mathrm{C}_{6} \mathrm{H}_{5}\right)_{4} \mathrm{As}\right] \mathrm{Br}$} \\
IX & {$\left[\left(\mathrm{C}_{6} \mathrm{H}_{5}\right)_{4} \mathrm{As}\right] \mathrm{I}$} \\
X & {$\left[\left(\mathrm{C}_{6} \mathrm{H}_{5}\right)_{3} \mathrm{PCH}\right] \mathrm{Br}$} \\
XI & {$\left[\left(\mathrm{C}_{6} \mathrm{H}_{5}\right)_{3} \mathrm{PCH} \mathrm{HCH}_{3}\right] \mathrm{I}$} \\
\hline
\end{tabular}

vigorous stirring, $1.25 \mathrm{mmol}(0.32 \mathrm{~g})$ of iodine dissolved in $15 \mathrm{ml}$ acetonitrile. To the clear, dark red solution was added $2.5 \mathrm{mmol}(1.28 \mathrm{~g})$ of tetraphenylarsonium iodide dissolved in $30 \mathrm{ml}$ acetonitrile. After filtering, the volume of the solution was reduced to $20 \mathrm{ml}$ in vacuum. The clear dark red solution was placed in a refrigerator overnight. Yield $1.86 \mathrm{~g}(88 \%)$. M.p. $174-176{ }^{\circ} \mathrm{C}$. Anal. $\mathrm{C}_{30} \mathrm{H}_{25}$ AsI $_{2}$ Te: C, H, As, I, Te. The crystals form red monoclinic prisms, extended along the $a-c$ diagonal, with $a=9.94 \AA, b=23.12 \AA, c=13.59 \AA$, $\beta=108.4^{\circ}$. There are four formula units per unit cell, density, calc. 1.89 , found $1.88 \mathrm{~g} / \mathrm{cm}^{3}$. The space group, from systematic absences is $P 2_{1} / n$ (No. 14).

Tetraphenylarsonium bromoiodophenyltellurate(II), $\left[\left(\mathrm{C}_{6} \mathrm{H}_{5}\right)_{4} \mathrm{As}\right]\left[\mathrm{C}_{6} \mathrm{H}_{5} \mathrm{TeBrI}\right]$ (Number II, Table $1)$, was prepared in the same way as compound $I$, starting with $1.25 \mathrm{mmol}(0.5 \mathrm{~g})$ of diphenylditelluride, $1.25 \mathrm{mmol}(0.2 \mathrm{~g})$ of bromine, and $2.5 \mathrm{mmol}(1.28 \mathrm{~g})$ of tetraphenylarsonium iodide. The compound crystallized from $20 \mathrm{ml}$ of acetonitrile. Yield $86 \%$. M.p. $168-170^{\circ} \mathrm{C}$. Anal. $\mathrm{C}_{30} \mathrm{H}_{25} \mathrm{AsBrITe}: \mathrm{C}, \mathrm{H}, \mathrm{As}$, $\mathrm{Br}, \mathrm{I}, \mathrm{Te}$.

The crystals are isomorphous with those of the diiodo analogue, and show the same colour and morphology. The unit cell dimensions are: $a=9.89$ $\AA, b=23.09 \AA, c=13.48 \AA, \beta=108.5^{\circ}$, and density calc. 1.81 , found $1.82 \mathrm{~g} / \mathrm{cm}^{3}$.

Tetraphenylarsonium dibromophenyltellurate(II), $\left[\left(\mathrm{C}_{6} \mathrm{H}_{5}\right)_{4} \mathrm{As}\right]\left[\mathrm{C}_{6} \mathrm{H}_{5} \mathrm{TeBr}_{2}\right]$, (Number III, Table 1), was prepared in the same way as the diiodo analogue, I, starting with $1.34 \mathrm{mmol}(0.55 \mathrm{~g})$ of diphenylditelluride, $1.25 \mathrm{mmol}(0.2 \mathrm{~g})$ of bromine, and $2.72 \mathrm{mmol}(1.26 \mathrm{~g})$ of tetraphenylarsonium bromide. The compound crystallized from $15 \mathrm{ml}$ of acetonitrile. Yield $1.6 \mathrm{~g}(85 \%)$ based on the amount of bromine added. M.p. $158-160{ }^{\circ} \mathrm{C}$. Anal. $\mathrm{C}_{30} \mathrm{H}_{25} \mathrm{AsBr}_{2} \mathrm{Te}$ : C, $\mathrm{H}, \mathrm{As}, \mathrm{Br}, \mathrm{Te}$.

The crystals are orange red triclinic plates with $a=13.14 \AA, b=13.79 \AA, c=19.22 \AA, \alpha=110.2^{\circ}$, $\beta=110.1^{\circ}, \gamma=61.5^{\circ}$. The density, calc, for four formula units per unit cell is 1.77 , found $1.77 \mathrm{~g} / \mathrm{cm}^{3}$.

Tetraphenylarsonium bromochlorophenyltellurate(II), $\left[\left(\mathrm{C}_{6} \mathrm{H}_{5}\right)_{4} \mathrm{As}\right]\left[\mathrm{C}_{6} \mathrm{H}_{5} \mathrm{TeBrCl}\right]$, (Number IV, Table 1), was prepared in the same way as the dibromo analogue, III, starting with $1.34 \mathrm{mmol}$ $(0.55 \mathrm{~g})$ of diphenylditelluride, $1.25 \mathrm{mmol}(0.2 \mathrm{~g})$ of bromine, and $2.27 \mathrm{mmol}(1.13 \mathrm{~g})$ of tetraphenylarsonium chloride. The compound crystallized from $10 \mathrm{ml}$ of acetonitrile. Yield $1.4 \mathrm{~g} \mathrm{(80 \% )}$ based on the amount of bromine added. M.p. $138-140{ }^{\circ} \mathrm{C}$. Anal. $\mathrm{C}_{30} \mathrm{H}_{25} \mathrm{AsBrClTe}: \mathrm{C}, \mathrm{H}, \mathrm{As}, \mathrm{Br}, \mathrm{Cl}$, Te. The crystals are isomorphous with those of the dibromo analogue, and show the same colour and morphology. The unit cell dimensions are: $a=13.08 \AA$,

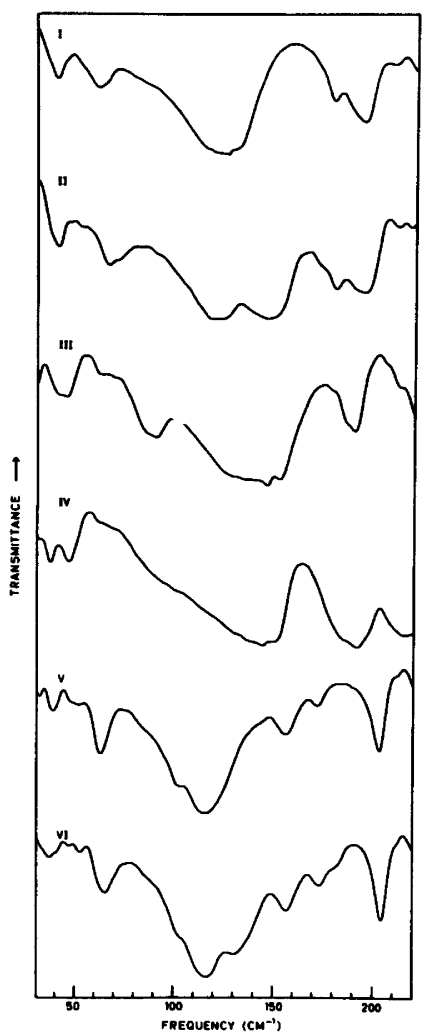

Fig. 1. Far infrared transmission spectra in the region $30-220 \mathrm{~cm}^{-1}$ of compounds I-VI as polyethylene pellets, concentrations $\mathrm{ca} .30 \mathrm{mg}$ of I-IV and $c a$. $18 \mathrm{mg}$ of $\mathrm{V}$ and $\mathrm{VI}$, resolution $4 \mathrm{~cm}^{-1}$, beamsplitter $12 \mu \mathrm{m}$ mylar, 30 scans. 
Table 2. The far infrared (IR) and Raman (R) spectral data for tetraphenylarsonium salts of dihalophenyltellurium(II)

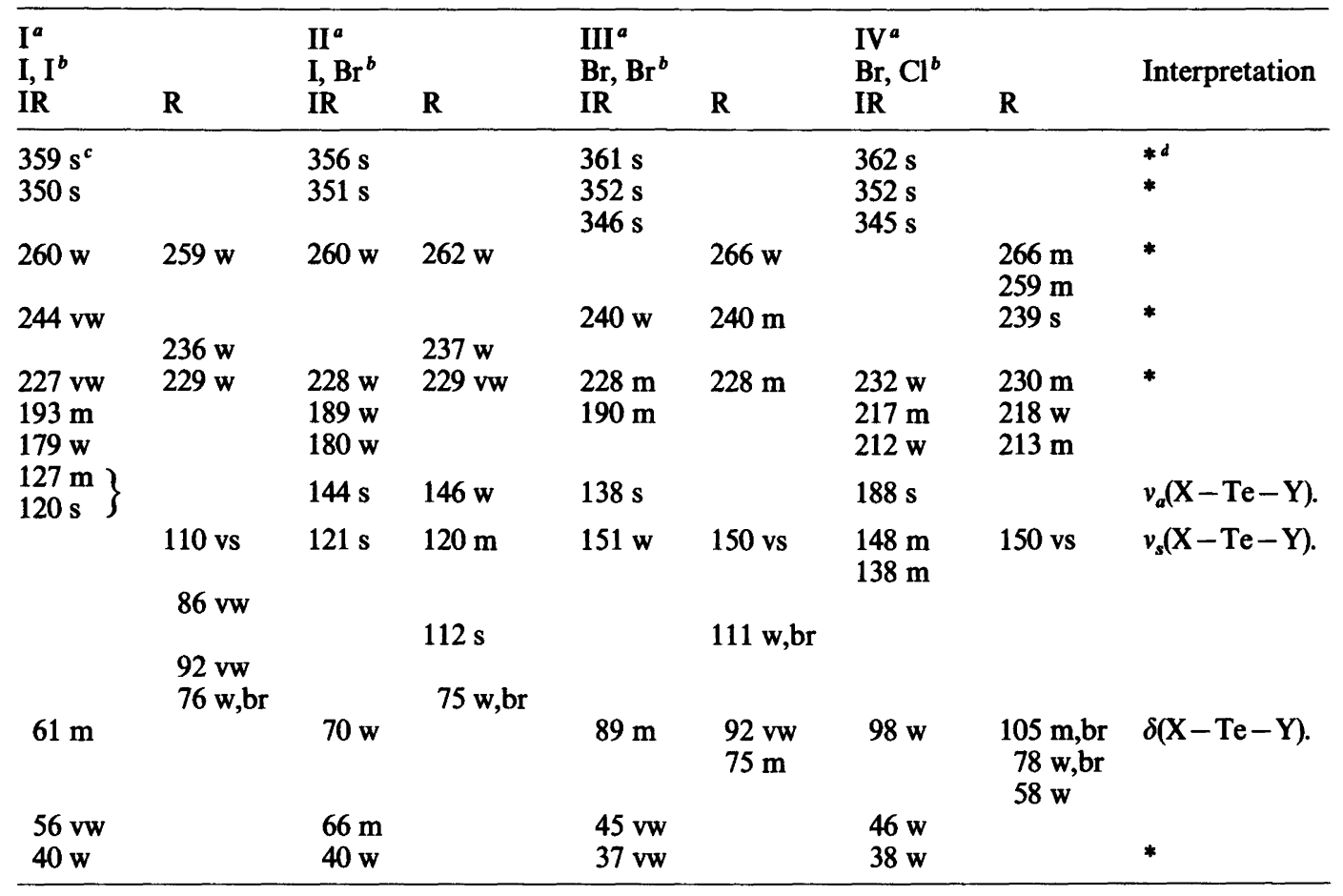

${ }^{a}$ Roman numerals refer to compounds listed in Table $1 .{ }^{b}$ Substituents $(\mathrm{X}-\mathrm{Te}-\mathrm{Y})$ in approximately linear arrangement. 'Abbreviations: s, strong; m, medium; w, weak; v, very; br, broad. dAsterisks indicate bands attributed to the cation.

$b=13.71 \AA, c=19.18 \AA, \alpha=110.3^{\circ}, \beta=110.0^{\circ}$, $\gamma=61.5^{\circ}$. Density, calc. 1.69 , found $1.68 \mathrm{~g} / \mathrm{cm}^{3}$.

Triphenylmethylphosphonium diiodo-paraethoxyphenyltellurate(II) (Number V, Table 1) and triphenylmethylphosphonium bromoiodo-paraethoxyphenyltellurate(II) (Number IV, Table 1), were prepared as reported previously. ${ }^{6}$

Spectral. The far IR spectra of the samples I-VI as well as of the cations VII-XI were recorded with an evacuable fast scan Fourier transform interferometer (Model $114 \mathrm{c}$ ) from Bruker. The interferometer was connected to a Nicolet 1180 computer and an interactive disc system. Beamsplitters of mylar of thicknesses $3.5,6,12$ and $23 \mu \mathrm{m}$ were employed and most of the spectra were recorded with resolution $4.0 \mathrm{~cm}^{-1}$, using $c a .30$ scans. Pellets were pressed, containing ca. $15 \mathrm{mg}$ and $30 \mathrm{mg}$ of the salts mixed with $200 \mathrm{mg}$ polyethylene (Rigidex).

A Cary model 81 Raman spectrometer equipped with a Spectra Physics model 125 A helium-neon laser and a Coherent Radiation Laboratory model
$52 \mathrm{G}$ argon ion laser were employed for the Raman recordings. Because of the yellow-brownish colour of the salts, spectra excited with the $6328 \AA$ heliumneon laser were superior to those excited with the argon ion laser. The samples were illuminated in the $180^{\circ}$ mode with $c a .50 \mathrm{mw}$ of laser energy on the sample.

\section{RESULTS AND DISCUSSION}

The observed infrared curves in the region 30 to $220 \mathrm{~cm}^{-1}$ obtained with a $12 \mu \mathrm{m}$ beam splitter of the compounds I-VI are shown in Fig. 1. The wave numbers of the IR and Raman bands of the tetra-phenyl arsonium salts (I-IV) and the triphenylmethylphosphonium salts (V and VI) are listed in Tables 2 and 3, respectively. For comparison, the bands of the reference compounds containing the appropriate cations are listed in Table 4. 
Table 3. The far infrared (IR) and Raman (R) spectral data for triphenyl methyl phosphonium salts of paramethoxyphenyltellurium(II).

\begin{tabular}{|c|c|c|c|c|}
\hline $\begin{array}{l}\text { V } \\
\text { II } \\
\text { IR }\end{array}$ & $\mathbf{R}$ & $\begin{array}{l}\text { VI } \\
\text { I Br } \\
\text { IR }\end{array}$ & $\mathbf{R}$ & Interpretation \\
\hline $\begin{array}{l}362 \mathrm{~m}^{a} \\
316 \mathrm{~m}\end{array}$ & & $\begin{array}{l}362 \mathrm{w} \\
318 \mathrm{~m}\end{array}$ & & $\begin{array}{l}* b \\
*\end{array}$ \\
\hline $\begin{array}{l}203 \mathrm{~s} \\
172 \mathrm{vw} \\
156 \mathrm{w}\end{array}$ & $229 w$ & $\begin{array}{l}204 \mathrm{~s} \\
173 \mathrm{vw}\end{array}$ & $228 w$ & $\begin{array}{l}* \\
* \\
* \\
*\end{array}$ \\
\hline $\begin{array}{l}156 \mathrm{w} \\
114 \mathrm{vs} \\
103 \mathrm{~m}\end{array}$ & $\begin{array}{l}119 \mathrm{~m} \\
100 \mathrm{~m}\end{array}$ & $\begin{array}{l}156 \mathrm{w} \\
128 \mathrm{~m} \\
114 \mathrm{vs}\end{array}$ & $\begin{array}{l}126 \mathrm{w} \\
120 \mathrm{~m}\end{array}$ & $\begin{array}{l}* \\
v_{a}(\mathrm{X}-\mathrm{Te}-\mathrm{Y}) \\
v_{s}(\mathrm{X}-\mathrm{Te}-\mathrm{Y})\end{array}$ \\
\hline & $\begin{array}{l}93 \mathrm{vw} \\
76 \mathrm{~m}\end{array}$ & & $\begin{array}{r}103 \mathrm{~m} \\
76 \mathrm{~m}\end{array}$ & \\
\hline $\begin{array}{l}63 \mathrm{~m} \\
41 \mathrm{vw}\end{array}$ & & $\begin{array}{l}65 \mathrm{~m} \\
49 \mathrm{w}\end{array}$ & & $\delta(\mathrm{X}-\mathrm{Te}-\mathrm{Y})$ \\
\hline
\end{tabular}

${ }^{a}$ Abbreviations, see Table $1 .{ }^{b}$ Attributed to the cation.

While divalent tellurium generally forms fourcoordinated complexes, it is well known that when a phenyl group is one of the ligands, the position trans to the phenyl group is vacant, making the compounds three-coordinated. Extensive X-ray crystallographic studies of three-coordinated tellurium (II) compounds revealed that the molecules have a T-shaped geometry. Crystallographic work including compounds I and II demonstrate a nearly linear arrangement of the $\mathrm{X}-\mathrm{Te}-\mathrm{Y}$ group. ${ }^{8}$ The results are in complete agreement with earlier work on phenyltellurium(II) complexes with halides and thiourea or selenourea as ligands. In all these compounds the deviation form linearity of the $\mathrm{X}-\mathrm{Te}-\mathrm{Y}$ groups is less than $8^{\circ}$ and the $\mathrm{Te}-\mathrm{C}$ bond nearly bisects the angle of the three-centre system. ${ }^{9-14}$

The vibrational modes of the $\mathrm{X}-\mathrm{Te}-\mathrm{Y}$ group can as a first approximation be separated from those of the rest of the molecule. This can be done with some confidence regarding the two $\mathrm{X}-\mathrm{Te}-\mathrm{Y}$ stretching vibrations which should be fairly independent of the bisecting phenyl group and appear as very intense bands. Much more uncertain are attempts to assign an " $\mathrm{X}-\mathrm{Te}-\mathrm{Y}$ bending mode". It is quite likely that the "linear, isolated molecule approximation" breaks down, giving rise to two bending vibrations. One of these is in the $\mathrm{X}-\mathrm{Te}(\mathrm{C})-\mathrm{Y}$ plane and is mixed with $\mathrm{C}-\mathrm{Te}$ stretch. We have only concerned ourselves with the other bending mode which is perpendicular to this plane and of quite low frequency.

In the "linear, isolated molecule approximation" the compounds I, III and V should have $D_{\infty h}$ symmetry, giving rise to one Raman active $\left(\Sigma_{g}^{+}\right)$

Table 4. The far infrared (IR) and Raman (R) spectral data for tetraphenylarsonium halides (VII - IX) and triphenylmethylphosphonium halides $(\mathrm{X}, \mathrm{XI})$.

\begin{tabular}{|c|c|c|c|c|c|c|c|c|c|}
\hline $\begin{array}{l}\text { VII } \\
\text { I } \\
\text { IR }\end{array}$ & $\mathbf{R}$ & $\begin{array}{l}\text { VIII } \\
\text { Br } \\
\text { IR }\end{array}$ & $\mathbf{R}$ & $\begin{array}{l}\text { IX } \\
\text { Cl } \\
\text { IR }\end{array}$ & $\mathbf{R}$ & $\begin{array}{l}X \\
I \\
\text { IR }\end{array}$ & $\mathbf{R}$ & $\begin{array}{l}\text { XI } \\
\text { Br } \\
\text { IR }\end{array}$ & $\mathbf{R}$ \\
\hline $\begin{array}{l}366 s^{a} \\
350 s\end{array}$ & & $365 \mathrm{~s}$ & $350 \mathrm{~s}$ & $\begin{array}{l}364 \mathrm{~s} \\
341 \mathrm{~s}\end{array}$ & $351 \mathrm{~s}$ & & & & \\
\hline $249 w$ & $\begin{array}{l}283 \mathrm{~m} \\
272 \mathrm{~m} \\
248 \mathrm{~s} \\
235 \mathrm{~s}\end{array}$ & $237 \mathrm{~s}$ & $283 \mathrm{~m}$ & $238 \mathrm{~m}$ & $\begin{array}{l}283 \mathrm{~m} \\
265 \mathrm{~m} \\
246 \mathrm{~s} \\
238 \mathrm{w}\end{array}$ & $\begin{array}{l}261 \mathrm{w} \\
256 \mathrm{~m} \\
242 \mathrm{~s}\end{array}$ & $\begin{array}{l}260 \text { vs } \\
255 \text { vs } \\
241 \mathrm{~s}\end{array}$ & $\begin{array}{l}285 \mathrm{vw} \\
267 \mathrm{vw} \\
257 \mathrm{~s} \\
241 \mathrm{~s}\end{array}$ & $267 \mathrm{~m}$ \\
\hline $\begin{array}{l}223 \mathrm{~s} \\
181 \mathrm{~s}\end{array}$ & $222 \mathrm{vw}$ & $187 \mathrm{~s}$ & $186 \mathrm{w}$ & $\begin{array}{l}231 \mathrm{w} \\
189 \mathrm{~s}\end{array}$ & $\begin{array}{l}229 \mathrm{~m} \\
192 \mathrm{vw}\end{array}$ & $168 \mathrm{~s}$ & $167 \mathrm{~m}$ & $\begin{array}{l}188 \mathrm{~m} \\
166 \mathrm{~m}\end{array}$ & $\begin{array}{l}188 w \\
167 w\end{array}$ \\
\hline $76 \mathrm{~s}$ & $105 \mathrm{~m}$ & $105 \mathrm{w}$ & $\begin{array}{l}83 w \\
75 \mathrm{~m}\end{array}$ & $\begin{array}{l}95 \mathrm{~s} \\
85 \mathrm{vs}\end{array}$ & $\begin{array}{l}93 \mathrm{~m} \\
83 \mathrm{w} \\
56 \mathrm{~m}\end{array}$ & $\begin{array}{l}63 \mathrm{~s} \\
46 \mathrm{~s}\end{array}$ & $\begin{array}{r}89 \mathrm{w} \\
65 \mathrm{~m}\end{array}$ & $\begin{array}{l}76 s \\
53 \mathrm{~s}\end{array}$ & $\begin{array}{l}96 \mathrm{w} \\
70 \mathrm{~s}\end{array}$ \\
\hline
\end{tabular}

${ }^{a}$ Abbreviations, see Table 1. 
and two IR active ( $\Sigma_{u}^{+}$and $\pi_{u}$ ) fundamentals. The less symmetric compounds II, IV and VI, however, should have $C_{\infty v}$ symmetry, with all the three fundamentals $\left(\Sigma^{+}, \Sigma^{+}\right.$and $\left.\pi\right)$ active in Raman and IR. Because of the pseudosymmetry of the three latter molecules we would expect the symmetric stretching mode to be intense in Raman, while the asymmetric mode should be intense in IR.

The asymmetric $v_{a}(\mathrm{X}-\mathrm{Te}-\mathrm{Y})$ and symmetric $v_{s}(\mathrm{X}-\mathrm{Te}-\mathrm{Y})$ stretching modes can be assigned with reasonably good confidence from the experimental data. For I, II and IV the $v_{a}$ was supposedly at higher wave numbers than $v_{s}$, while the opposite was true for compound III. Comparison between Tables 1 and 3, reveals that most of the IR and Raman bands not assigned to the $\mathrm{X}-\mathrm{Te}-\mathrm{Y}$ group can be attributed to cation vibrations. Our assignment of the bending mode $\delta(\mathrm{X}-\mathrm{Te}-\mathrm{Y})$ (because of the presence of the $\mathrm{Te}-\mathrm{C}$ bond to the phenyl group) should be considered very tentative.

In Table 2 the corresponding assignments are listed for compounds V and VI. They differ somewhat from those reported by Petragnani et al. ${ }^{6}$ which were based upon Raman spectra only. Our results for compounds I - IV reveal without doubt that the far IR data are essential for assigning $v_{a}(\mathrm{X}-\mathrm{Te}-\mathrm{Y})$ in the symmetric (I and III) as well as in the asymmetric (II and IV) compounds. As apparent from Table 3 a very strong IR band at $114 \mathrm{~cm}^{-1}$ is observed for $\mathrm{V}$ as well as for VI and is attributed as $v_{s}$ and $v_{a}$, respectively. We might state very approximately that the " $\mathrm{C}-\mathrm{I}$ and $\mathrm{C}-\mathrm{Br}$ stretching modes" are observed at $120 \mathrm{~cm}^{-1}(114$ $\mathrm{cm}^{-1}$ in IR) and $128 \mathrm{~cm}^{-1}\left(126 \mathrm{~cm}^{-1}\right.$ in Raman), respectively in compound IV. The two stretching modes $v_{s}$ and $v_{a}$ for V and VI were at somewhat lower wave numbers than for the corresponding I and II, indicating weaker bonds in the former molecules.

Force constant calculations. As was done in our earlier spectroscopic study of three-coordinated tellurium(II) compounds, ${ }^{5}$ force fields were derived for the present molecules. These calculations are very simple for the "linear isolated molecule approximation". In the quadratic force field, two stretching constants $k_{1}$ and $k_{2}$ and an interaction term $k_{12}$ are sufficient to calculate the two stretching frequencies $v_{a}$ and $v_{s}$. One bending constant $k_{\alpha}$ is sufficient to calculate the bending frequency $\delta(\mathrm{X}-\mathrm{Te}-\mathrm{Y})$.

Using the bond distances $\mathrm{Te}-\mathrm{I}=2.95$, $\mathrm{Te}-\mathrm{Br}=2.87$ and $\mathrm{Te}-\mathrm{Cl}=2.70 \AA$, preliminary
Table 5. Observed and calculated vibrational fundamentals of the $\mathrm{X}-\mathrm{Te}-\mathrm{Y}$ group.

\begin{tabular}{|c|c|c|c|c|c|c|}
\hline \multicolumn{2}{|c|}{ Compound Linkage } & \multicolumn{2}{|l|}{$v_{a}$} & \multicolumn{2}{|l|}{$v_{s}$} & \multirow{2}{*}{$\begin{array}{l}\delta \\
\text { obs }^{a}\end{array}$} \\
\hline & & obs & calc & obs & calc & \\
\hline I & $\mathrm{I}-\mathrm{Te}-\mathrm{I}$ & 120 & 121 & 110 & 113 & 61 \\
\hline II & $\mathrm{I}-\mathrm{Te}-\mathrm{Br}$ & 144 & 145 & 120 & 118 & 70 \\
\hline III & $\mathrm{Br}-\mathrm{Te}-\mathrm{B}$ & 138 & 144 & 150 & 147 & 89 \\
\hline IV & $\mathrm{Br}-\mathrm{Te}-\mathrm{C}$ & 188 & 191 & 150 & 143 & 98 \\
\hline $\mathbf{V}^{b}$ & $\mathrm{I}-\mathrm{Te}-\mathrm{I}$ & 114 & - & 100 & - & 63 \\
\hline $\mathrm{VI}^{b}$ & $\mathrm{I}-\mathrm{Te}-\mathrm{Br}$ & 128 & - & 120 & - & 65 \\
\hline
\end{tabular}

${ }^{a}$ The bending force constants $k_{\alpha}$ were adjusted to make the observed and calculated frequencies equal. ${ }^{b}$ Not included in the least squares fit because of different chemical surroundings.

values of $k_{\mathrm{Te}-\mathrm{I}}=k_{\mathrm{Te}-\mathrm{Br}}=k_{\mathrm{Te}-\mathrm{I}}=0.8 \mathrm{mdyn} / \AA$ and $k_{12}=0.3 \mathrm{mdyn} / \AA$ were employed. With the aid of an iteration procedure the three $k_{\mathrm{Te}-\mathrm{x}}$ force constants were allowed to vary while the specific interaction term $k_{12}$ was assumed to be common for all the molecules. The results are listed in Table 5 , and as is apparent the agreement between the 8 observed stretching frequencies of compounds I - IV and the calculated values are satisfactory, employing the following four independent parameters: $k_{\mathrm{Te}-1}$ $=0.66, k_{\mathrm{Te}-\mathrm{Br}}=0.73, k_{\mathrm{Te}-\mathrm{Cl}}=0.64$ and $k_{12}(\mathrm{Te}-\mathrm{X} /$ $\mathrm{Te}-\mathrm{Y})=0.29 \mathrm{mdyn} / \AA$. Since the assigned fundamentals for compounds $\mathrm{V}$ and VI were systematically lower than for I-IV (of different chemical surroundings) they were not included in the calculations. The following values for the bending force constant $k_{\alpha}$ were calculated: $k_{\mathrm{I}-\mathrm{Te}_{\mathrm{I}} \mathrm{I}}=0.40$, $k_{\mathrm{I}-\mathrm{Te}-\mathrm{Br}}=0.47, \quad k_{\mathrm{Br}-\mathrm{Te}-\mathrm{Br}}=0.68, \quad k_{\mathrm{Br}-\mathrm{Te}-\mathrm{Cl}}=0.60$ $\operatorname{mdyn} \AA / \mathrm{rad}^{2}$.

It was attempted to calculate the splittings of the $\mathrm{X}-\mathrm{Te}-\mathrm{Y}$ bending modes by introducing the third ligand, the phenyl group, as a point mass. Using the same $k_{\alpha}$ for the "in plane" and "out of plane" bending and $k_{\mathrm{C}-\mathrm{Te}}=2.2 \mathrm{mdyn} / \AA$ a splitting of the bending modes of only a few wavenumbers were calculated.

Acknowledgement. The Fourier transform spectrometer was partly finance by a grant from NAVF. R.S. acknowledges a fellowship sponsored by IAESTE.

\section{REFERENCES}

1. Foss, O. Acta Chem. Scand. 6 (1952) 306.

2. Vicentini, G., Giesbrecht, E. and Pitombo, L. Chem. Ber. 92 (1959) 40. 
3. Schulz, P. and Klar, G. Z. Naturforsch. Teil B 30 (1975) 40.

4. Hauge, S. and Vikane, O. Acta Chem. Scand. 27 (1973) 3596.

5. Klæboe, P. and Vikane, O. Acta Chem. Scand. A 31 (1977) 120.

6. Petragnani, N., Torres, L., Wynne, K. J. and Williams, D. J. J. Organometal. Chem. 76 (1974) 241.

7. Haller, W. S. and Irgolic, K. J. J. Organometal. Chem. 38 (1972) 97.

8. Vikane, O. To be published.

9. Hauge, S. and Vikane, O. Acta Chem. Scand. A 29 (1975) 755.

10. Vikane, O. Acta Chem. Scand. A 29 (1975) 738.

11. Vikane, O. Acta Chem. Scand. A 29 (1975) 763.

12. Vikane, O. Acta Chem. Scand. A 29 (1975) 787.

13. Foss, O. and Marøy, K. Acta Chem. Scand. 20 (1966) 123.

14. Foss, O. and Husebye, S. Acta Chem. Scand. 20 (1966) 132.

Received March 16, 1978. 